\title{
A comparison of the mechanical engineering and safety engineering student's ICT attitudes at the Obuda University
}

\author{
Gabor Kiss ${ }^{1 \mathrm{a}}$ and Antonia Szasz ${ }^{2}$ \\ ${ }^{1}$ Obuda University, Becsi ut 96/b, Budapest H-1034, Hungary \\ ${ }^{2}$ Denis Gabor College, Budapest, Hungary
}

\begin{abstract}
Communication and technology are critical to education. However, using technology in education is not an easy task as communication barriers emerge. The aim of this research is to analyze the ICT attitudes from different faculties at the Obuda University that is between the mechanical engineering students and safety engineering students from the Donát Bánki Mechanical Safety Engineer Faculty. The students from these two groups will use different ICT tool at work after their graduation; the mechanical engineering students will work mostly with designer ICT tools, the safety engineering students will use security systems. It would be important to know whether instructors, when using ICT, have to follow different teaching methods and approaches in these two different groups or not. We measured the ICT attitude with a tool consisting of 23 items (Likert scaled. We worked with 361 students. The data analysis was performed with SPSS software using descriptive statistics and Mann-Whitney test. The results show both groups having the same positive ICT attitude however with one difference.
\end{abstract}

\section{Introduction}

The aim of this research is to analyze the ICT attitudes of mechanical engineering and safety engineering students. The students from these two groups will use different ICT tools in their professional life after graduation; the mechanical engineering students work mostly with designer ICT tools, but the safety engineering students use mostly security systems. Our research focused on whether the instructors have to follow different teaching methods in these two different groups or not and whether the students have different ICT attitudes or not. We measured the ICT attitude using Likert scale. Some earlier research analyzed the ICT literacy of the students in Hungary on different levels $[4 ; 5 ; 8 ; 9]$.

\footnotetext{
${ }^{a}$ Corresponding author: kiss.gabor@bgk.uni-obuda. hu
} 


\section{ICT attitude research}

A general definition of attitude toward an object, $\mathrm{A}(\mathrm{O})$, in the discipline of social psychology is provided by Eagly and Chaiken defining attitude as "a psychological tendency that is expressed by evaluating a particular entity with some degree of favor and disfavor" [12]. They further comment on their conceptual understanding of the term psychological tendency as referring to "a state that is internal to the person" and evaluating to "all classes of evaluative responding, whether overt or covert, cognitive, affective or behavioral". In line with the conceptualization of the Theories of Reasoned Action (TRA), Fishbein and Ajzen defined attitude towards a behavior, A(B), as "an individual's positive or negative feelings (evaluative affect) about performing the target behavior" [13]. This definition has been established in the Information Systems (IS) domain since the introduction of the Technology Acceptance Model (TAM) in 1989.

Yang and Yoo propose that attitude should be divided into two constructs, cognitive attitude and affective attitude. They referred this dyadic attitude approach to Petty et al., who argued that "the most common classification for the basis of attitude is affect and cognition". The affective attitude is thereby defined as a person likes of an object, and the cognitive refers to a person's thoughts about the object. For this study in order to analyze attitude, we took into consideration all classes of responses, whether overt or covert, cognitive, affective or behavioral that helped us to identify an individual's positive or negative feelings about the use of ICT.

\section{Networked readiness index in Hungary}

When The Global Information Technology Report (GITR) and the Networked Readiness Index (NRI) were created some 12 years ago, the attention of decision makers and investors was on adopting business and financial strategies that would allow them to develop in the context of a fast-moving but nascent Internet economy. Over more than a decade, the NRI has provided decision makers with a useful conceptual framework to evaluate the impact of information and communication technologies (ICTs) at a global level, and to benchmark the ICT readiness and the usage of their economies. The networked readiness framework that shapes the NRI, comprises of four sub-indexes that measure:

- The environment for ICTs;

- The readiness of a society to use ICTs;

- The actual usage of all main stakeholders;

- The impacts that ICTs generate in the economy and in society.

The three first sub-indexes can be regarded as the drivers that establish the conditions for the results of the fourth sub index. So, in Table 1, we can see in a general way the position that Hungary occupies.

Table 1. 2013 The networked readiness index

\begin{tabular}{llll}
\hline \multirow{2}{*}{ Index Name } & \multicolumn{3}{c}{ Hungary } \\
\cline { 2 - 4 } & 2013 & Score & 2012 \\
& Rank & & Rank \\
\hline The Networked Readiness Index & 44 & 4.29 & 43 \\
\hline
\end{tabular}


We focus on the two sub-indexes, Readiness Index and Usage Index, because they provide us with information about ICT penetration, use and involvement. The readiness sub index (Table 2.), with a total of 12 variables, measures the degree of a society's will and ability to make good use of an affordable ICT infrastructure and digital content.

The infrastructure and digital content pillar (five variables) captures the development of ICT infrastructure (including mobile network coverage, international Internet bandwidth, secure Internet servers, and electricity production) as well as the accessibility of digital content.

The affordability pillar (three variables) assesses the cost of accessing ICTs, either via mobile telephony or fixed broadband Internet, as well as the level of competition in the Internet and telephony sectors that determine this cost.

The skills pillar (four variables) gauges the ability of a society to make effective use of ICTs thanks to the existence of basic educational skills captured by the quality of the educational system, the level of adult literacy, and the rate of secondary education enrollment.

Table 2. 2013 Readiness subindex

\begin{tabular}{lll}
\hline & Rank & Score \\
\hline Readiness Sub index and Pillars & 59 & 4.87 \\
\hline Infrastructure and Digital Content & 58 & 4,25 \\
\hline Affordability & 74 & 5,10 \\
\hline Skills & 42 & 5,24 \\
\hline
\end{tabular}

The usage sub index assesses the individual efforts of the main social agents - that is individuals, business, and government - to increase their ICT usage for their daily activities with other agents. It includes 16 variables (Table 3), but we are only presenting individual dimension.

The individual usage pillar (seven variables) measures ICT penetration, understanding and usage and diffusion at the individual level, using indicators such as the number of mobile phone subscriptions, individuals using the Internet, households with a personal computer (PC), households with Internet access, both fixed and mobile broadband subscriptions, and the use of social networks.

Table 3. Individual usage subindex

\begin{tabular}{lll}
\hline & Rank & Score \\
\hline Usage Sub index And Pillars & 46 & 4,07 \\
\hline Individual Usage & 42 & 4,67 \\
\hline
\end{tabular}

The impact sub index measures the broad economic and social impacts resulting from ICT to boost competitiveness and well-being; it reflects the transformations toward an ICT and technology oriented economy and society. It includes a total of eight variables; here we are presenting only social impacts.

The social impacts pillar (four variables) aims at assessing the ICT-driven improvements in well-being thanks to their impacts on the environment, education, energy consumption, health progress, or more-active civil participation (Table 4.). At the moment, because of data limitations, this pillar focuses on measuring the extent to which governments are becoming more efficient in the use of ICTs and providing increasing online services to their citizens, and thus improving their e-participation. It also assesses the 
extent to which ICTs are present in education, as a proxy for the potential benefits that are associated with the use of ICTs in education.

Table 4. 2013 Impact subindex

\begin{tabular}{llc}
\hline & Rank & Score \\
\hline Impact Subindex and Pillars & 42 & 4.00 \\
\hline Social Impacts & 40 & 4.35 \\
\hline
\end{tabular}

Hungary occupies a middle high position in the rank in every indicator. Hungary who is at the 44th position has remained stable with little variation in the rankings, despite relatively well developed ICT infrastructures and penetration rates. However, serious weaknesses in their innovation systems hinder their capacity to properly integrate their digital development into a well-performing ecosystem that allows for higher innovation rates.

\section{Analyzing students' attitudes}

The purpose of this study is to compare the ICT attitude of mechanical engineering and safety engineering students.

Table 5. Attitude items

\begin{tabular}{|c|c|c|}
\hline $\begin{array}{l}\text { Number } \\
\text { of item }\end{array}$ & Item & $\begin{array}{c}\text { Negative } \\
\text { item }\end{array}$ \\
\hline 1 & I believe that ICT are very important for my learning at present & \\
\hline 2 & I believe that teachers should use ICT to facilitate student learning & \\
\hline 3 & The ICT doesn't facilitate an active learning as student. & Yes \\
\hline 4 & Teachers need to make an effort of to harness the teaching potential of ICT & \\
\hline 5 & I think it's good to go progressively integrating ICT in my studies & \\
\hline 6 & I would like to study at a center that will feature more technological resources & \\
\hline 7 & I feel comfortable using a methodology that incorporates ICT & \\
\hline 8 & I feel overwhelmed by the amount of information on the Internet. & Yes \\
\hline 9 & The use of ICT in the classroom could hinder the dynamic of the class & Yes \\
\hline 10 & At the moment of selecting a University I will take in consideration how ICT is being used in teaching. & \\
\hline 11 & My learning will lose effectiveness with incorporating ICT & Yes \\
\hline 12 & It is irrelevant the use of ICT to learn & Yes \\
\hline 13 & I like to work with other classmates that use ICT in their academics training & \\
\hline 14 & The study subjects can be enriched for the opportunities provided by ICT & \\
\hline 15 & It makes little sense to believe that ICT will change education & \\
\hline 16 & The ICT doesn't allow to students learn basic intellectual skills. & Yes \\
\hline 17 & Should prioritize the improvement of current ICT infrastructure & \\
\hline 18 & I don't care to know the odds of ICT in learning process & Yes \\
\hline 19 & I don't think appropriate introduce ICT in study & Yes \\
\hline 21 & My learning as student will not improve for the use of ICT & Yes \\
\hline 22 & It worry me that in my future as student I have to use more the ICT & Yes \\
\hline 23 & The ICT give me flexibility of space and time to communicate me & \\
\hline 24 & The use of the ICT allows students develop a more meaningful learning & \\
\hline
\end{tabular}

We have used Liker-type rating scales to measure the ICT attitude of students [11]. Likert scales are commonly used to measure attitude, providing a range of responses to a given question or statement [3]. There were 5 categories of response, from (for example) 
$1=$ strongly disagree up to $5=$ strongly agree. This instrument of ICT attitude of students was composed by 24 items (Table 5 ).

The reliability of the questionnaire: The reliability of the questionnaire obtained by the technique of Cronbach- $\alpha$ was 0.475; we have received acceptable answers for the most important questions. The questionnaire include 10 negative questions, in this case the lowest score shows strongly agree; while the highest score shows strongly disagree. We have recoded the scores of these items and we have got as Cronbach value 0,831 it means the reliability of the questionnaire is good.

The number of participants: The sample consisted of 361 students, 265 mechanical engineering students and 96 safety engineering students.

\section{The results of independent samples Mann-Whitney $U$ test}

The Likert scale is ordinary scale, and as such we can calculate mean, min, max, median, modus, std. dev. etc. We can use the nonparametric tests where we need ordinary variables. We have two independent samples so we could use the Mann-Whitney-Wilcoxon test for 2 samples [1]. The Mann-Whitney-Wilcoxon test seems better choice versus t test by Likert-type data [2], because it is testing the medians of the samples.

We used the Mann-Whitney independent sample U test of SPSS to compare the means of scores taken by the students. Monitoring was held on $\mathrm{p}=5 \%$ significancy level in the whole analyzing process.

\subsection{Comparing the ICT attitude}

If we summarize the scores of all items and make the comparison we can see the ICT attitude of students. We need to transfer the value of negative items to positive and then start the analysis process. The result of Mann-Whitney $U$ test on the total scores has shown significant difference between the 2 group of students - positive attitude, $p=0.000$.

We calculated the mean scores by items and also calculated the difference between them grouped by faculties. Then we can made analysis process with Mann-Whitney U test (Table VI). According to the table we can find significant differences by many. According to the table we can find significant differences by the most attitude items. The mechanical engineering students have more positive attitude by "I believe that teachers should use ICT to facilitate student learning", "I feel comfortable using a methodology that incorporates ICT", "At the moment of selecting a University I will take in consideration how ICT is being used in teaching", "It is irrelevant the use of ICT to learn", "It makes little sense to believe that ICT will change education", "Should prioritize the improvement of current ICT infrastructure"," I don't think appropriate introduce ICT in study". It means they need more ICT in education process at the university by teacher they are waiting for more ICT, but at home until the learning process it would be not so important.

On other hand the safety engineering students have more positive by the following items: "The ICT doesn't facilitate an active learning as student"," Teachers need to make an effort of to harness the teaching potential of ICT", "I would like to study at a center that will feature more technological resources", "The use of ICT in the classroom could hinder the dynamic of the class", "I like to work with other classmates that use ICT in their academics training", "The study subjects can be enriched for the opportunities provided by ICT", "I don't care to know the odds of ICT in learning process", "My learning as student will not improve for the use of ICT", "The ICT give me flexibility of space and time to communicate me". It means the safety engineering students like to use ICT at home and at the university too, they can use ICT until the study without any press by the teacher. The 
mechanical engineer students need more help to show the way to use ICT until the study at home too.

Table 6 . Means and $\mathrm{P}$ values by attitude items

\begin{tabular}{|c|c|c|c|c|c|}
\hline \multirow{2}{*}{$\begin{array}{l}\text { Number } \\
\text { of item }\end{array}$} & \multirow{2}{*}{ Item } & $\begin{array}{l}\text { Mechanical } \\
\text { engineering }\end{array}$ & $\begin{array}{c}\text { Safety } \\
\text { engineering }\end{array}$ & \multirow{2}{*}{$\mathrm{p}$} & \multirow{2}{*}{ sig. dif. } \\
\hline & & Mean (score) & $\begin{array}{l}\text { Mean } \\
\text { (score) }\end{array}$ & & \\
\hline 1 & I believe that ICT are very important for my learning at present & 4,26 & 4,36 & 0,532 & no \\
\hline 2 & $\begin{array}{l}\text { I believe that teachers should use ICT to facilitate student } \\
\text { learning }\end{array}$ & 4,26 & 1,69 & 0,000 & yes \\
\hline 3 & The ICT doesn't facilitate an active learning as student. & 1,86 & 3,80 & 0,000 & yes \\
\hline 4 & $\begin{array}{l}\text { Teachers need to make an effort of to harness the teaching } \\
\text { potential of ICT }\end{array}$ & 3,73 & 4,23 & 0,000 & yes \\
\hline 5 & I think it's good to go progressively integrating ICT in my studies & 3,88 & 4,04 & 0,064 & no \\
\hline 6 & $\begin{array}{l}\text { I would like to study at a center that will feature more } \\
\text { technological resources }\end{array}$ & 3,79 & 4,17 & 0,000 & yes \\
\hline 7 & I feel comfortable using a methodology that incorporates ICT & 3,92 & 2,05 & 0,000 & yes \\
\hline 8 & I feel overwhelmed by the amount of information on the Internet. & 2,20 & 2,05 & 0,423 & no \\
\hline 9 & $\begin{array}{l}\text { The use of ICT in the classroom could hinder the dynamic of } \\
\text { the class }\end{array}$ & 2,21 & 2,44 & 0,030 & yes \\
\hline 10 & $\begin{array}{l}\text { At the moment of selecting a University I will take in } \\
\text { consideration how ICT is being used in teaching. }\end{array}$ & 2,40 & 2,01 & 0,000 & yes \\
\hline 11 & My learning will lose effectiveness with incorporating ICT & 2,35 & 2,06 & 0,114 & no \\
\hline 12 & It is irrelevant the use of ICT to learn & 2,12 & 3,90 & 0,000 & yes \\
\hline 13 & $\begin{array}{l}\text { I like to work with other classmates that use ICT in their } \\
\text { academics training }\end{array}$ & 3,69 & 3,93 & 0,005 & yes \\
\hline 14 & $\begin{array}{l}\text { The study subjects can be enriched for the opportunities } \\
\text { provided by ICT }\end{array}$ & 3,84 & 3,99 & 0,041 & yes \\
\hline 15 & It makes little sense to believe that ICT will change education & 3,74 & 2,54 & 0,000 & yes \\
\hline 16 & $\begin{array}{l}\text { The ICT doesn't allow to students learn basic intellectual } \\
\text { skills. }\end{array}$ & 2,68 & 3,94 & 0,000 & yes \\
\hline 17 & $\begin{array}{l}\text { Should prioritize the improvement of current ICT } \\
\text { infrastructure }\end{array}$ & 3,67 & 2,04 & 0,000 & yes \\
\hline 18 & I don't care to know the odds of ICT in learning process & 2,14 & 1,77 & 0,000 & yes \\
\hline 19 & I don't think appropriate introduce ICT in study & 1,91 & 4,43 & 0,000 & yes \\
\hline 21 & My learning as student will not improve for the use of ICT & 1,95 & 1,59 & 0,001 & yes \\
\hline 22 & $\begin{array}{l}\text { It worry me that in my future as student I have to use more the } \\
\text { ICT }\end{array}$ & 2,31 & 2,07 & 0,114 & no \\
\hline 23 & $\begin{array}{l}\text { The ICT give me flexibility of space and time to communicate } \\
\text { me }\end{array}$ & 3,71 & 4,08 & 0,000 & yes \\
\hline 24 & $\begin{array}{l}\text { The use of the ICT allows students develop a more meaningful } \\
\text { learning }\end{array}$ & 3,79 & 3,90 & 0,713 & no \\
\hline
\end{tabular}

Figure 1 shows the scores of the students from different faculties; we can see that the attitude of mechanical engineering students is more positive than the safety engineering students. It was more important for the mechanical engineering students by choosing a university where use more ICT the teachers until the lessons. It means the teachers at the faculty of Mechanical have to make more attention on the ICT in education process, because the students on this faculty interested more for these tools and the teachers can use this motivation to transfer the knowledge to the students. (Fig. 1., Fig. 2, Fig.3.). 


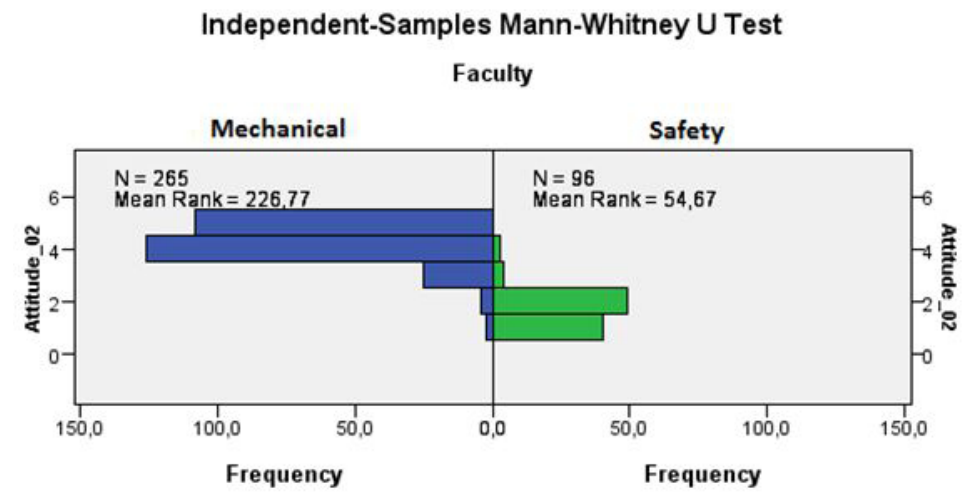

\section{Independent-Samples Mann-Whitney U Test}

Faculty

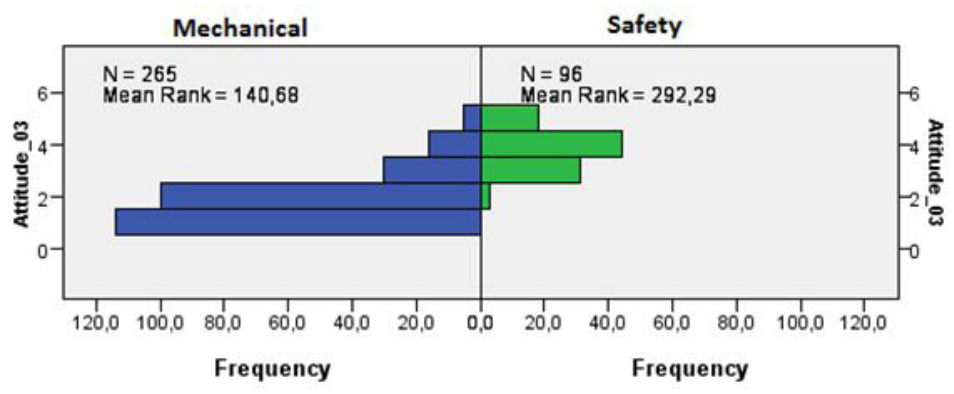

Independent-Samples Mann-Whitney U Test

Faculty

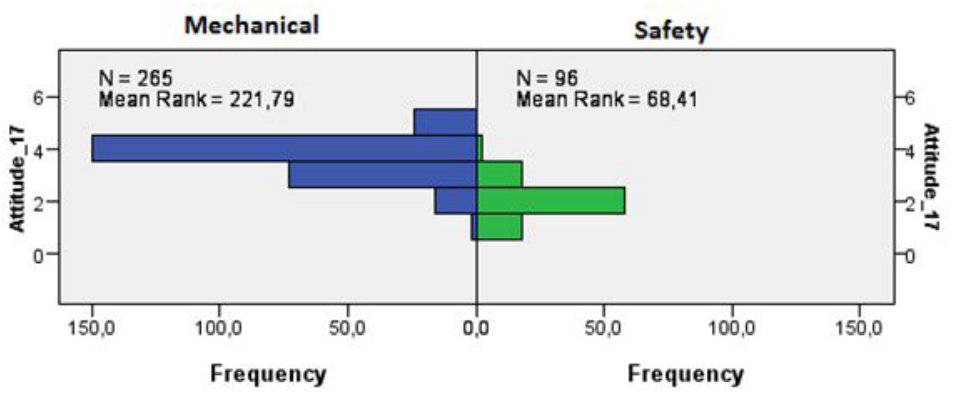

\section{Conclusion}

We analyzed the ICT attitude from different faculty at Obuda University to see if we can we find any differences by mechanical engineering students and safety engineering students. The results of the analysis show the students different positive ICT attitude by the most items. For the mechanical engineering students is critical to choose a university based on how ICT is being used in teaching. It means the instructors at the faculty of Mechanics have to make more attention on the ICT in education process, because the students on this faculty are very interested in ICT tools until the learning process at the university. On the 
other hand the teachers at the Safety Faculty will be more effective to show to the advantage of using ICT at home for the safety engineering students because they would use it at home too.

\section{References}

1. Boonyasit W., Appropriate statistical analysis for two independent groups of Likerttype data, Dissertation, American University Washington (2011)

2. De Winter J. C. F. and Dodou D., Five-Point Likert Items: t test versus Mann-WhitneyWilcoxon, Practical Assessment, Research \& Evaluation, Vol.: 15, No.: 11, ISSN: 1531-7714 (2010)

3. Jamieson, S., Likert scales: how to (ab)use them, MEDICAL EDUCATION 2004; Vol.: 38, pp 1217-1218 (2004).

4. Kiss G., The survey measuring the informatics skills of the entering Students at Budapest Tech, Bánki Donát Faculty of Mechanical and Safety Engineering, 7th IEEE International Symposium on Intelligent System and Informatics, Subotica, Serbia, ISBN: 978-1-4244-5348-1, pp:395-397, IEEE Xplore digital library Digital Object Identifier: 10.1109/SISY.2009.5291125 (2009)

5. Kiss G. A., comparison of informatics skills by genders of Hungarian grammar school students, 8th International Conference on Applied Informatics, Eger, ISBN 9789894 72 3, Vol. 2., pp. 17-27 (2010a)

6. Kiss G. A Comparison of Informatics Skills by Genders when entering Higher Education in Hungary, 8th IEEE International Symposium on Intelligent System and Informatics, Subotica, Serbia, ISBN: 978-1-4244-7395-3, pp. 179-182, IEEE Catalog Number: CFP1084C-CDR, IEEE Xplore digital library Digital Object Identifier: 10.1109/SISY.2010.5647280 (2010b)

7. Kiss G. A Comparison of Programming Skills by Genders of Hungarian Grammar School Students, Symposia and Workshops on Ubiquitous, Autonomic and Trusted Computing, Xi'An, China, ISBN: 978-0-7695-4272-0, pp. 24-30, IEEE Catalog Number: CFP1075H-CDR, IEEE Xplore digital library Digital Object Identifier: 10.1109/UIC-ATC.2010.83 (2010c)

8. Kiss G., A Comparison of Informatics Skills by schooltypes in the 9-10th grades in Hungary, International Journal of Advanced Research in Computer Science, Vol.: 2, No. 2, ISSN: 0976-5697, pp. 417-428 (2011a)

9. Kiss G., Measuring Student's Computer Science Knowledge at the End of the primary stage in Hungary, 9th IEEE International Symposium on Applied Machine Intelligence and Informatics, Smolenice, Slovakia, ISBN: 978-1-4244-7428-8, pp. 19-22, IEEE Catalog Number: CFP1108E-CDR, IEEE Xplore digital library Digital Object Identifier: 10.1109/SAMI.2011.5738880 (2011b).

10. Kiss G., Measuring Hungarian and Slovakian Students' IT Skills and Programming Knowledge, Acta Polytechnica Hungarica, Vol. 9., No. 6, 2012, ISSN: 1785-8860, pp. 195-210 (2012)

11. Likert, R., A technique for the measurement of attitudes, Archives of Psychology, Vol.: 27, No.: 140, pp 44-55 (1932)

12. A. Eagly A \& Chaiken S., The psychology of attitudes. USA: Wadsworth, Belmont, (1993)

13. Fishbein M. \& Ajzen I., Belief, attitude, intention, and behavior: An introduction to theory and research. USA: Addison Wesley, Reading, MA, (1975) 